\title{
Aldona Żurek
}

Instytut Socjologii

Uniwersytet im. Adama Mickiewicza w Poznaniu

\section{WIĘZI SPOŁECZNE A ZJAWISKO SAMOTNOŚCI I OSAMOTNIENIA}

\section{WPROWADZENIE}

Samotność, osamotnienie, izolacja społeczna, dystrofia więzi, wyobcowanie, atomizacja społeczeństwa to tylko niektóre z określeń, jakie pojawiają się wtedy, gdy mówimy o ciemnych stronach przemian współczesności. Ten rodzaj diagnozy dotyczy cech współczesnego społeczeństwa, lecz ma także związek z kondycją jednostek. Ich przyczyny mają charakter multikazualny, jednak wśród głównych wymienia się: odchodzenie od kolektywistycznych wzorów życia, zmniejszające się znaczenie nieformalnych małych grup społecznych (a szczególnie tych, które mają charakter wspólnotowy), wzrastające znaczenie, jakie mają przelotne i formalne w swoim charakterze stosunki społeczne, wirtualność przynajmniej części aktywności, jakiej oddają się ludzie oraz przemiany życia rodzinnego.

Czy zatem odejście od wspólnotowych form życia społecznego, przelotność kontaktów i kruchość więzi społecznych oznacza, że niepotrzebne i niefunkcjonalne stają się struktury inne niż te, które oparte są na więziach formalnych i organizacyjnych? Czy struktury oparte na silnych więziach są jeszcze potrzebne? Takie pytania pojawiają się wtedy, gdy osamotnienie, a zwłaszcza samotność stają się głównym elementem ludzkiego losu.

W społecznej naturze człowieka istnieje potrzeba posiadania bliskich emocjonalnie i wielozakresowych więzi społecznych. Tego rodzaju relacje istnieją tylko w bezpośrednich relacjach, które obecne są w strukturach określanych jako nieformalne grupy społeczne, bądź w diadach, opartych na podobnych zasadach, jakie obowiązują we wspólnotach. To rodzina, mimo co i raz wieszczonej śmierci, jest taką właśnie ostoją i niszą społeczną, która pozwala na pojawienie się poczucia zakorzenienia społecznego. Jednak spora część wspólnot rodzinnych przestaje pełnić taką właśnie funkcję. Modernizacja współczesnej rodziny z jednej strony doprowadziła do uwolnienia potencjałów, które mieli jej członkowie, 
dzięki czemu mogli oni realizować swoje aktywności zgodnie z potrzebami, jakie odczuwali (co szczególnie dotyczy kobiet i dzieci). Z drugiej jednak spowodowała, że poczucie bezpieczeństwa, stabilności prowadzące do osiągania dobrostanu przestało być dane jedynie z powodu więzów krwi, jakie łączą jednostki w ramach i pomiędzy pokoleniami. W skryptach istniejących w społecznej świadomości pozostawanie członkiem rodziny nie tylko przestało być utożsamiane z godnym życiem, ale również nie jest już synonimem szczęśliwego życia. Wielość ścieżek karier życiowych, form i postaci życia jest udziałem, w naszym kręgu kulturowym, zarówno kobiet, jak i mężczyzn. Ich wybór jest nie tylko przywilejem, ale jednocześnie nakazem czy zobowiązaniem, a jego skutki, dobre bądź złe, ponosi jednostka. Ochronna funkcja, jaka pełniły kiedyś wspólnoty uległa zawieszeniu lub znacznemu ograniczeniu.

\section{KONTEKSTY ANALIZY RELACJI JEDNOSTKI Z INNYMI LUDŹMI}

Aby ocenić, kto i w jakich okolicznościach znaleźć się może w sytuacji, w której brak jest obecności innych ludzi, czy to faktycznie, czy w subiektywnej ocenie osoby osamotnionej, uporządkować trzeba pole znaczeniowe związane z tymi zjawiskami.

\section{Osamotnienie}

Osamotnienie jest taką sytuacją w życiu człowieka, kiedy brak jest relacji z innymi osobami. Osoba osamotniona większość czasu wciągu doby spędza bez towarzystwa innych ludzi, zatem nie może zainicjować ani podtrzymywać znaczących dla niej relacji społecznych (Żurek 2008: 90). Osamotnienie może pojawić się jako wynik decyzji, polegającej na drastycznym ograniczeniu liczby bezpośrednich relacji i stosunków społecznych, co prowadzi do pojawienia się stylu życia, gdzie środowisko społeczne, w którym funkcjonuje jednostka jest znikome lub nie ma go w ogóle.

Drugą postacią osamotnienia jest ta, która nie zależy od decyzji człowiekajest w pewnym sensie na nią skazany czy pozbawiony wyboru. Poza wynikającymi z prawa karnego okolicznościami, osamotnienie, na które jednostka nie ma wpływu dotyczy pewnych specyficznych kategorii społecznych, do których należą: osoby niepełnosprawne, ciężko chore, należące do mniejszości etnicznych, bezdomni i ludzie, którzy ukończyli 75 rok życia (Phillipson 2004). Wskazać także można na pewną ogólniejszą zależność pomiędzy nierównością społeczną a osamotnieniem (de Jong Gierveld, Van Tilburg, Dykstra 2006: 493). 
Osamotnienie w niektórych badaniach analizowane jest w aspekcie nie tylko ilości, ale również jakości stosunków społecznych i ich wpływu na wybrane aspekty stylu życia. Izolacja, jak wynika z badań, poprzedzona jest fazą pasywności społecznej, odnoszącej się zarówno do formalnych, jak i nieformalnych stosunków społecznych (Hortulanus 2005: 245). Ciekawe jest także stwierdzenie, że dążenie do autonomii i niezależności, które są cechą współczesnych postmaterialistycznych społeczeństw, prowadzić może do atrofii więzi społecznych, a $\mathrm{w}$ efekcie do obumierania podstawowej tkanki życia społecznego, jakimi są bezpośrednie relacje zachodzące między ludźmi. W efekcie możemy obawiać się pojawienia się licznej rzeszy ludzi luźnych, dla których aktualizacja ich statusu, jako członków społeczeństwa, ma miejsce jedynie ze względu na krótkotrwale, przelotne i niezobowiązujące relacje społeczne.

Osamotnienie może mieć miejsce także ze względu na określone cechy statusowe (o których była mowa wcześniej), a także cechy społeczności lokalnych (zwłaszcza tych silnie zurbanizowanych). Unikanie nawiązywania stosunków społecznych może mieć swoje źródła w braku kompetencji społecznych, umiejętności prowadzenia konwersacji czy uchylania się przed ewentualnymi zobowiązaniami, jakie z takich relacji mogą wynikać (Hortulanus 2005: 247).

Skutki, jakie przynosi osamotnienie mają jednostkowy i społeczny charakter. Indywidualne dotyczą trudności w realizowanych codziennych aktywnościach, zwłaszcza jeśli osoba, którą dotknęła izolacja ma jakąś postać dysfunkcji organizmu. Nie mniej dolegliwe skutki dotyczą kłopotów zdrowotnych osoby izolowanej. Są nimi problemy mające psychiczną naturę: niemożność radzenia sobie ze stresem, problemy ze snem, częstsze zachorowania na choroby psychiczne, rośnie także ryzyko zachorowań na choroby zakaźne i choroby niedokrwienne (Bruhn 2011: 29). Można powiedzieć, że osoba osamotniona jest jednostką chorą, która ma zaburzenia zachowania, emocji i myślenia (Hortulanus 2005: 29).

Wzrost liczby osób izolowanych przynosi także konsekwencje odnoszące się do posunięć, jakie będą musiały być podejmowane w ramach realizowanej przez państwo polityki społecznej. Brak oparcia w strukturach społecznych, niemożność odwoływania się do potencjału, jaki przynoszą sieci społeczne, powodować będzie konieczność podejmowania dodatkowych działań, które te pierwotne źródła, jakimi są małe grupy, będą musiały zastąpić.

\section{Wykluczenie społeczne}

Wykluczenie społeczne jest pojęciem węższym znaczeniowo od izolacji i osamotnienia. Najogólniej rzecz ujmując, oznacza ono brak możliwości podejmowania aktywności w wybranych sferach życia publicznego czy szerszych zbiorowościach. Ponadto najczęściej jest ono używane po to, aby opisać stan 
niemożności uczestniczenia w życiu publicznym i społecznym, brak dostępu do instytucji i organizacji społecznych (lub w wybranych jego obszarach), grup i kategorii społecznych, rzadziej zaś jednostek. Brak relacji społecznych nie oznacza w tym przypadku absolutnego charakteru, lecz odnosi się jedynie do wybranej sfery życia.

\section{Prywatność}

Pomiędzy osamotnieniem a posiadaniem złożonych sieci społecznych sytuuje się zjawisko prywatności. Choć ma ono długą historię, to dopiero w czasach nowożytnych dążenie do poszerzenia sfery wolności, niezależności i autonomii, wyrażające się osiąganiem stanu, w którym jednostka jest chroniona przed niepożądaną obecnością innych ludzi, dotyczącą ich fizycznego i psychicznego oddziaływania, stało się społecznie cenioną wartością (Bok 1982). Ideał prywatności określony jest przez szereg norm kulturowych, jednocześnie uzyskał instytucjonalną ochronę.

Prywatność jest stanem odosobnienia, który przybierać może kilka postaci. Po pierwsze jest nią samotność, która w pewnych sytuacjach przeradzać się może w osamotnienie. Prywatność to także anonimowość, która jest pożądanym i częstym zjawiskiem we współczesnych wysoce zurbanizowanych środowiskach, pozwalająca na ucieczkę od wielu mechanizmów kontrolnych. Jednak anonimowość to nie tylko poszerzenie autonomii i wolności człowieka, ale także, w skrajnym przypadku, pojawienie się niepożądanego zjawiska anomii. Można również spojrzeć na prywatność rozumiejąc ją jako rezerwę, najbardziej dostępną i najstarszą jej postać (Westin 1968). Rezerwa nawiązuje do sfery niedopowiedzenia, jaka ma miejsce w kontaktach międzyludzkich. Jest ona elementem taktu, grzeczności i dobrego wychowania. Ma zawsze kontekstową postać, zależy bowiem od sytuacji, w której „zaszyte” są normy określające dystanse, jakie w interakcjach należy zachowywać. W końcu zaś prywatność przyjmuje także postać zażyłości występującej między bliskimi dla siebie osobami, która zobowiązuje do dyskrecji wobec szerszych zbiorowości.

O ile osamotnienie oznacza, że osoby nią dotknięte mają ograniczoną liczbę znaczących więzi społecznych, o tyle samotność może pojawić się również wtedy, gdy więzi takie występują. Pozostawanie osobą samotną mieści się na kontinuum pomiędzy posiadaniem relacji i stosunków społecznych a osamotnieniem. Umieszczenie się w którymś z miejsc owego kontinuum zależne jest od indywidualnych standardów, jakie stosuje osoba uznająca się za samotną. Mając niewiele kontaktów społecznych, nie musimy czuć się osamotnieni, ceniąc sobie prywatność ponad utrzymywanie relacji w ramach sieci i struktur społecznych (de Jong Gierveld, Van Tilburg, Dykstra 2006: 486). 


\section{Samotność}

Cechą wspólną definicji, zwłaszcza tworzonych na użytek psychologicznych badań, jest podkreślanie, iż samotność jest indywidualnie doświadczanym dyskomfortem, wynikającym z subiektywnej oceny na temat pożądanej i istniejącej sieci relacji społecznych. Owo nieprzyjemne doświadczenie może zmieniać się wraz ze zmianą cyklu rozwojowego człowieka czy jego kontekstowymi doświadczeniami (ibidem: 485). Deficyty, które są odczuwane przez człowieka, ujmowane w aspekcie sieci utrzymywanych relacji, mogą mieć jakościowy, lub ilościowy charakter (Perlman, Peplau 1981: 31). Zatem, mimo że jednostka jest zakorzeniona w życiu społecznym (można wskazać na istnienie licznych afiliacji), a jej więzi określić można jako wartościowe, to jej osobiste doświadczenia wskazywać mogą na występowanie samotności.

Samotność może stać się stanem pozytywnym lub negatywnym, pozytywna oznacza dobrowolne wycofanie się z codziennych relacji z innymi ludźmi, po to, aby znaleźć poczucie prywatności. Samotność negatywna jest stanem odczuwanym jako przykry, bądź z powodu braku relacji osobistych o charakterze emocjonalnym czy intymnym, bądź z powodu odczuwania deficytów relacji z ważnymi innymi (de Jong Gierveld, Van Tilburg, Dykstra 2006: 486). Pojawia się także typologia samotności gdzie wyróżnia się samotność emocjonalną i społeczną (Weiss 1973). Ta pierwsza ma miejsce wskutek wygaśnięcia intymnych, bliskich relacji opartych na emocjach. Poczucie samotności emocjonalnej zanika dopiero wtedy, gdy poczucie pustki po stracie ukochanej osoby wypełnione zostaje nową więzią (Stroebe, Stroebe, Abakoumkin, Schut,1996). Natomiast samotność społeczna łączy się z brakiem czy niedostatkami społecznych sieci składających się ze znaczących dla jednostki osób, takich jak przyjaciele, koledzy, krewni. Szczególnie dotkliwie odczuwany jest brak przyjaciół, z którymi łączyłyby się podobne zainteresowania czy spędzanie czasu wolnego (de Jong Gierveld, Van Tilburg, Dykstra 2006: 487).

W badaniach poświęconych samotności stosuje się równolegle trzy podejścia: kognitywne, kontekstualne oraz łączące ich cechy (de Jong Gierveld, Van Tilburg, Dykstra: 488). Wyróżnikiem podejścia indywidualnego jest akcentowanie doświadczeń indywidualnych osamotnionej osoby, a zwłaszcza oceny związków między realnymi a oczekiwanymi relacjami społecznymi. Badania obejmują szerokie spektrum relacji, od intymnych po niezobowiązujące znajomości, wskazując na znaczenie, jakie mają wybrane relacje rodzinne (w tym dotyczące rodzeństwa, małżeńskie, łączące rodziców i dzieci), przyjacielskie, sąsiedzkie a także nierodzinnych (przyjacielskie, koleżeńskie). Studia badawcze poświęcone są również wielkości i kompozycji sieci relacji, jakie utrzymuje osoba samotna. Okazuje się na przykład, że już cztery utrzymywane relacje uznać można za wystarczające dla ochrony przed samotnością (Van Tilburg, 1990). Z badań wynika także, że ludzie posiadający jednocześnie silne i słabe więzi są mniej narażeni na 
samotność niż osoby mające tylko silne więzi. Szczególnie istotne z tego punktu widzenia są porównania $\mathrm{z}$ istniejącymi $\mathrm{w}$ środowisku społecznym standardami, które wpływają na wielkość deficytów w tym względzie (Perlman, Peplau 1981). W podejściu indywidualnym szereg analiz dotyczy cech statusowych i osobistych osób samotnych.

Cechą podejścia kontekstowego jest skupianie się na analizach standardów odnoszących się do oceny relacji społecznych oraz na wpływ czynników społecznych, kulturowych i ekonomicznych dla tworzenia i podtrzymywania relacji społecznych (de Jong Gierveld, Van Tilburg, Dykstra 2006: 491). Standardy społeczne istniejące $\mathrm{w}$ danym środowisku nie tylko wyznaczają optymalną liczbę relacji w ramach sieci, ale określają również wzajemne zobowiązania, jakie im towarzyszą. Analizy dotyczą także modelu świadomościowego struktury, do której należy jednostka (przyjęcia wartości kolektywistycznych lub indywidualistycznych) i jego wpływu na pojawiania się poczucia samotności. Interesujące są również badania poświęcone cechom kultur narodowych, w których zawarte są cechy sprzyjające pojawianiu się poczucia samotności. Okazuje się, że im kultura jest bardziej indywidualistyczna, tym ryzyko to zwiększa się.

\section{Wyobcowanie}

Kategorią zbliżoną do pojęcia samotności jest wyobcowanie. W optyce przyjmowanej przez socjologów wyobcowanie wiązane jest z ze zjawiskiem inności lub obcości człowieka w środowisku społecznym, ze względu na wyjątkowe, różne od typowych cechy jakie posiada. Częściej jednak w teoriach pojawia się pojęcie alienacji. Polega ono na utracie tożsamości, pojawiającej się jako skutek nieutożsamiania się ze społecznością lokalną lub społeczeństwem. Najczęściej ma miejsce w dużych, heterogenicznych aglomeracjach miejskich oraz w skupiskach ludności napływowej (migracje zarobkowe, mniejszości etniczne). Poczucie wyobcowania najpierw wiązane z opisem kondycji robotników w XX wieku nabrało nowego sensu i odnoszone było do malejącego znaczenia podstawowych więzi, jakie łączyły człowieka z grupami pierwotnymi, rozszerzając jego znaczenie z kontekstu strukturalnego i sytuacyjnego na zjawiska kulturowe i polityczne. $\mathrm{Z}$ powodu niejednoznaczności przypisywanych znaczeń odnoszonych do alienacji wyróżnia się kilka jej rodzajów. Mówi się o alienacji interpersonalnej, pracy, polityczno-ekonomicznej oraz społeczno-kulturowej (Schacht 1971). Pojawia się również typologia ujmująca zjawisko alienacji w jego subiektywnym wymiarze. W nawiązaniu do koncepcji M. Seemana (Seeman 1975) wyróżnia się alienację przyjmującą postać: bezsilności (brak poczucia kontroli nad życiem), bezsensu (niski poziom oczekiwań dotyczących podejmowanej aktywności), anomii (zanik norm), samowyobcowania (postępowanie zgodne $\mathrm{z}$ własnymi standardami jest szkodliwe) oraz izolacji (osamotnienie). 


\section{Kapitał społeczny}

Kategoriami analitycznymi, które służyć mogą diagnozie przy ocenie stopnia samotności i pojawienia się izolacji społecznej są kapitał społeczny, sieci społeczne, a przede wszystkim więź społeczna.

Nie wdając się w niuanse i kontrowersje związane z pojęciem kapitału społecznego, można przyjąć, że są nimi wzajemne związki zachodzące w sieci relacji społecznych (struktur społecznych) stających się zasobami jednostki, z których może korzystać, czerpiąc z nich zyski. Siłą kapitału społecznego, jakim dysponuje jednostka jest zaufanie, lojalność, niezawodność i wzajemne zobowiązania (Putnam 2008). Dotyczy to związków w ramach i między sieciami, i zawiera się w zasobach, które pochodzą z istniejących relacji (Bruhn 2011: 79). Cechą kapitału społecznego, zwłaszcza ujmowanego z indywidualnej a nie zinstytucjonalizowanej perspektywy, jest to, że jego zasoby wskazują i na stopień zakorzenienia jednostki w społeczeństwie, a także na jakościową jego naturę. Można bowiem określić zarówno liczbę połączeń jednostki w sieci zależności, oceniając siłę kapitału społecznego, jak i potencjał tkwiący w utrzymywanych sieciach. Należy przy tym podkreślić, że kapitał społeczny ma zarówno swoją realną postać, jak i potencjalny charakter, wiążący się z siłą zobowiązań, jakie zawarte są w normach wzajemności. Nadto posiadany przez jednostkę kapitał może ulec powiększeniu dzięki sięganiu po potrzebne zasoby, korzystając z kapitału innych osób należących do sieci, lub kapitału grup (organizacji), do których się należy (Bourdieu 1986: 249).

Osoba, którą określić można jako osamotnioną ma zdecydowanie ograniczony kapitał społeczny ze względu na dwie okoliczności. Brak statusu członka grupy powoduje, że nie może liczyć na wsparcie (o różnym zresztą charakterze) wtedy, gdy uważa je za potrzebne. W zamian pojawia się możliwość korzystania ze świadczeń społecznych. Jednak pomoc instytucjonalna obwarowana jest szeregiem wstępnych warunków, a jednocześnie nie ma ona tak kompleksowej natury jak ta oferowana przez grupy. Po drugie zaś nieposiadanie silnych i złożonych sieci nieformalnych, w tym wynikających z uczestnictwa w małych, nieformalnych grupach, w taki sam sposób ogranicza możliwości związane z aktywnościami, jakie człowiek chciałby (lub musi) podejmować (Small 2009). Natomiast w odniesieniu do oceny tego, czy w życiu człowieka pojawia się zjawisko pustki społecznej, kapitał społeczny nie wydaje się wystarczającym narzędziem. Człowiek mający poczucie samotności, de facto może posiadać złożony i duży kapitał społeczny, który jednak w jego subiektywnej ocenie, albo za sprawą standardów dotyczących liczby, jakości czy mocy więzi, uznaje za niewystarczający. Pewne cechy statusowe (np. wiek, brak aktywności zawodowej), zajmowanie peryferyjnych pozycji w strukturach oraz brak złożoności sieci społecznych, decydować mogą o tym, że posiadany kapitał społeczny uznany będzie przez człowieka za niewystarczający, co prowadzić może do pojawienia się poczucia samotności. 


\section{Sieci społeczne}

Sieci społeczne, które obejmują ten rodzaj relacji, który wykracza poza płaszczyznę struktur społecznych, także są źródłem zasobów, z których korzystać może jednostka. Zawierają szersze spektrum relacji i związków społecznych, ponieważ obejmują także niestrukturalizowaną płaszczyznę życia społecznego. Człowiek podejmuje wysiłek, aby tworzyć sieci społeczne, po to, aby osiągać określone korzyści mające odniesienie do życia codziennego, albo związane z celami mającymi ogólniejszą naturę. Wyróżnić można kilka strategii związanych z działaniami tego rodzaju. Jednostka może inicjować powstanie więzi z inną osobą, by zwiększyć liczbę połączeń w sieci i w rezultacie mieć dostęp do większej liczby potrzebnych jej zasobów. Po drugie podejmuje działania powodujące powstanie więzi społecznych, aby utworzyć nowe połączenia w ramach sieci, mając w planie jakiś konkretny cel (rodzi się tu analogia do używanego w mowie potocznej „szukania dojść”). Inicjowanie relacji w ramach sieci może stać się też celem autotelicznym, często po to by zaspokajać potrzebę afiliacji czy potrzeby prestiżowe. W końcu pojawiają się i takie działania, związane z tworzeniem sieci społecznych, w których cel nie gra żadnej roli, ponieważ zachowania związane z tworzeniem sieci pojawiają się w sposób niezobowiązujący, wynikają bowiem z realizowanego stylu życia czy habitusu (Small 2009).

\section{Więzi społeczne}

Rudymentarnym czynnikiem pozwalającym na trwanie i rozwój społeczeństwa są więzi społeczne. Ta kategoria analityczna wykorzystywana jest zarówno w analizach, w których więzi społeczne ujmowane są z perspektywy struktur społecznych (dominującej w społeczeństwie więzi społecznej), jak i wtedy, gdy określa się miejsce i funkcję, jaką pełni jednostka wobec swojego środowiska społecznego.

Mimo że w teoriach socjologicznych i innych naukach społecznych więź społeczna jest po wielokroć opisywana i za jej sprawą diagnozowana jest kondycja społeczeństw (por. Beck 2002; Watters 2004; Castells 2007; Maffesoli 2008; Putnam 2008), nie wypracowano jednej wiodącej koncepcji, która z jednej strony wskazywałaby na specyfikę tej kategorii, pozwalając odróżnić ją od takich pojęć jak: spójność grupowa, związki społeczne, relacje, stosunki społeczne czy kapitał społeczny. Z drugiej zaś takiej teorii, która jednoznacznie wskazywałaby na czynniki, jakie na więź społeczną się składają. Istnieją oczywiście tego rodzaju propozycje, istniejące również w polskiej socjologii przedmiotu (por. Szczepański 1965; Rybicki 1979; Ossowski 1983; Jacher 1987), jednak nie są one powszechnie podzielane. Ustalenia tego rodzaju pozwoliłyby na określanie stanu wyjściowego przy konstruowaniu więzi, a także na tworzenie typologii więzi. Częściej bowiem 
określa się wskaźniki opisujące intensywność, jakość więzi czy miejsce w jakim się formuje (silne/słabe, emocjonalne/rzeczowe, osobowe/bezosobowe, pozytywne/negatywne, zrzeszeniowe/wspólnotowe, naturalne/stanowione) niż wskazuje na czynniki wystarczające i konieczne po to, aby wypowiadać się na temat jej istoty. Jeśli dodać że istnieją trzy podstawowe podejścia badawcze: stanowisko subiektywne, społeczno-strukturalne oraz subiektywno-strukturalne (Turowski 1993) wraz z towarzyszącymi im koncepcjami i teoriami, zagmatwanie towarzyszące tej kategorii niestety tylko się powiększa.

Przyjmując ustalenia wynikające przede wszystkim z badań empirycznych poświęconych więziom łączącym jednostki w ramach mikrostruktur społecznych, a więc takich, które oparte są na interakcjach i bezpośrednich stosunkach społecznych, można zauważyć, że więziom przypisywany jest kompleks, czasami niespójnych ze sobą cech. Po pierwsze po to, aby pojawiła się więź społeczna potrzebna jest jakaś postać powiązania między ludźmi, wynikająca $\mathrm{z}$ ich uczestnictwa w strukturach, lub polegająca na udziale w sieciach społecznych. Zakłada się także, że jeśli analizuje się więź z poziomu cech jednostek konieczne są bezpośrednie (realne lub wirtualne) kontakty_między jednostkami. Te zresztą stają się wskaźnikiem siły więzi, określanej częstotliwością kontaktów.

Więzi społeczne tworzone są z intencjonalnych pobudek (mówimy o motywach i zachowaniach, które sprzyjają powstawaniu więzi), ale możliwe jest także sytuacyjne czy kontekstowe ich powstanie (niejako przy okazji spotkania się ludzi). Więzi można także narzucać lub wchodzić w takie relacje, w których konieczność utrzymywania więzi jest niejako automatyczna. Przyczyny pojawienia się danego rodzaju więzi dobrze wyjaśnia koncepcja, zgodnie z którą prymarnym czynnikiem więzi społecznych są stosunki społeczne. Te zaś mają swoją podstawę, czyli powód ich istnienia (relacje krewniacze, osadnicze, organizacyjne, rzeczowe).

$\mathrm{Z}$ tą cechą więzi związana jest kolejna, a mianowicie to, że zawierają w sobie komponenty emocjonalne $\mathrm{i} /$ lub rzeczowe, utylitarne. Więzi istnieją i są pielęgnowane z jakiegoś powodu - uczuć, celu jaki chce się osiągnąć, tradycji, przyzwyczajenia. Sposób, w jaki przejawiają się więzi związany jest z konkretnymi zachowaniami i działaniami, regulowanymi przez społecznie (lub grupowo) akceptowanym systemem aksjonormatywny. Jedną z istotniejszych i mających ogólną naturę norm jest ta, która mówi o wzajemnych zależnościach, jakie mają miejsce między osobami połączonymi więzią. Transakcyjność więzi ma miejsce zarówno wtedy, gdy występuje nierównowaga ze względu na stosunki władzy, jak i wówczas, gdy więź łączy osoby o podobnym czy zbliżonym statusie społecznym. Ważnym aspektem więzi jest także świadomość ich występowania oraz to, że efektem refleksji jednostki staje się jej afirmowanie lub nieakceptowanie. Wrogość bowiem, podobnie jak pozytywne zaangażowanie stać się może siłą spajająca ludzi.

Próbując uchwycić najważniejsze cechy więzi odróżniające tę kategorię od pokrewnych można przyjąć, że sprowadza się to do wystąpienia: styczności, wzajemnych kontaktów mających na celu zaspokojenie istotnych potrzeb jednostki, 
świadomości istnienia więzi, respektowanie podobnego systemu aksjonormatywnego a także wzajemnych zależności, które tworzą ramy takich relacji. Więzi manifestują się w konkretnych zachowaniach i działaniach ludzi, które podejmowane są w kontekście oddziaływania innych.

Odróżniając dwa rodzaje więzi: bezpośrednie i niebezpośrednie (mogą mieć osobisty - wirtualny, oraz nieosobisty - wynikający z posiadanego statusu społecznego, lub zajmowanej pozycji społecznej, charakter) zjawisko samotność i osamotnienie oznacza pojawianie się deficytów $\mathrm{w}$ związku z pierwszym rodzajem więzi.

W odniesieniu do dotychczasowych wyników badań nad samotnością i osamotnieniem należy mieć na uwadze, iż więzi tworzone są i podtrzymywane z jakiegoś powodu, a także że istnieje wiele takich sytuacji społecznych, gdzie powstają one bez celowej intencji. To z kolei oznacza, że kontekst sytuacyjny staje się równie istotny, jak celowe i silnie zmotywowane działania człowieka, podejmowane $\mathrm{w}$ celu budowania więzi. Intencjonalne tworzenie więzi jest tym owocniejsze im więcej jest okazji do spotkania z innymi ludźmi. Istotne są także społeczne kompetencje w zakresie współdziałania z innymi osobami. Jeśli ich brakuje, oddziaływania wzajemne są zbyt słabą podstawą do budowania więzi (Small 2009). W końcu należy mieć także na względzie to, że uczestnictwo w organizacjach stają się doskonałą okazją do budowania więzi mających nieformalny charakter. Rosnące znaczenie, jakie ma dla współczesnego człowieka praca zawodowa, sprawia, że staje się ona także istotnym źródłem zadowolenia, co przekłada się na budowanie satysfakcjonujących więzi właśnie w tym środowisku (Dahlin, Kelly, Moen 2008: 721).

\section{PODSUMOWANIE - OSAMOTNIENIE A WIĘZI SPOŁECZNE}

Aby zdiagnozować fakt wystąpienia samotności i izolacji społecznej, należy odnieść się do kompleksu więzi łączących jednostkę z innymi osobami, a nie poprzestawać na diagnozie dotyczącej tylko jednej z nich. Oceniając charakter więzi bezpośrednich należy zastosować czworakiego rodzaju kryteria. Jednocześnie można je uznać za elementy składające się na model więzi. Są to kryteria ilościowe, treściowe, jakościowe raz odnoszące się do mocy więzi.

Kryterium ilościowe dotyczy liczby relacji (stosunków) społecznych, jakie łączą jednostkę z innymi osobami. Kryterium to jest jednocześnie podstawowe dla ewaluacji osamotnienia człowieka. Jak wynika z badań, dodatkowym czynnikiem łączącym się z tym kryterium jest ich zróżnicowanie. Osoba o zdywersyfikowanych więziach, a więc pochodzących z wielu sieci i struktur rzadziej jest osamotniona i samotna niż taka, którą łączą silne więzi tylko z jednym typem grupy społecznej. Liczba stosunków społecznych łącząca jednostkę z jej otoczeniem jest podstawową przesłanką, jaka wykorzystywana jest przy diagnozowaniu izo- 
lacji społecznej w jakiej znalazła się jednostka. Należy jednak uwzględnić również jej cechy statusowe, takie jak np. wiek. Istnieje przypuszczenie, że seniorzy ograniczają liczbę utrzymywanych relacji społecznych do tych, które przynoszą im oczekiwane korzyści, działają celowo racjonalnie. Podtrzymując wybrane tylko więzi społeczne, nie dążą do izolacji, ale proaktywnie zarządzają swoim środowiskiem społecznym (Baltes, Carstensen 1999). Wskaźnik ilościowy nie jest wystarczający, zwłaszcza przy ewaluacji samotności człowieka, przede wszystkim dlatego, że źródeł samotności należy poszukiwać w kryteriach, jakie stosuje jednostka. Natomiast osamotnienie jest bezpośrednio związane z liczbą znaczących więzi społecznych. Osoby utrzymujące minimalną liczbę więzi z definicji określane są jako wyizolowane.

Drugim elementem jest treść więzi. Ma ona bezpośredni związek zarówno z podstawą stosunków społecznych, na których jest oparta, jak i z rodzajem potrzeb, które za pośrednictwem więzi są zaspokajane. Choć nie zawsze jest tak, że więzi powstają z jakiegoś powodu (możliwe jest ich przypadkowe, nieplanowane powstanie), to jednak ich utrzymanie jest świadomym i refleksyjnym procesem, ponieważ wymaga nakładu sił i środków. Także w przypadku więzi, których źródłem są kulturowo i społecznie zdefiniowane relacje społeczne (co w szczególności dotyczy więzi rodzinnych), to trwanie i rozwój uzależnione jest od decyzji, jakie podejmuje jednostka. Część relacji społecznych ma szczególną naturę, ze względu na wieloaspektowy charakter więzi. Należą do nich zwłaszcza te, które łączą jednostkę z małżonkiem (partnerem). Związane jest to z wielostronnością utrzymywanych relacji, ponieważ osoba taka, zarówno dla kobiet, jak i mężczyzn, jest źródłem fizycznego, finansowego oraz psychicznego dobrostanu (Waite, Gallagher 2000). Ponad to istnieje możliwość korzystania z zasobów kapitału społecznego partnera zawartych w utrzymywanych przez niego relacjach (Pinquart, Sórensen 2001).

Równie istotną rolę pełnią także więzi, jakie występują między rodzicami a dziećmi, ze względu na wzajemne transfery międzypokoleniowe, obejmujące dary materialne, dary czasu i przestrzeni (Szukalski 2002). Zmniejszenie zagrożenia pojawieniem się poczucia samotności dają także więzi utrzymywane z przyjaciółmi, choć ich treść ograniczona jest najczęściej do zajęć związanych z czasem wolnym, wymianą poglądów i kształtowaniem postaw oraz okazywaniem uczuć (Blieszner, Adams 1992). Obok tego występują także więzi, które mają jednostronny charakter, to znaczy utrzymywane są ze względu na daną, konkretną sferę aktywności. Bez względu na źródła więzi, kluczową rolę w zdefiniowaniu ich charakteru pełnią potrzeby jednostki, w tym sensie, że treść więzi można określić jako odpowiedź na brak dobrostanu. Zarówno faktyczny stan osamotnienia, jak i subiektywne poczucie samotności ma miejsce wtedy, gdy człowiek nie jest w stanie zaspokoić istotnych dla niego potrzeb. Strategią, jaka efektywnie przeciwdziała samotności, a zwłaszcza izolacji społecznej, jest posiadanie zazębiających się sieci relacji, dzięki czemu jeden rodzaj więzi może być zastępowany przez inne. 
Czynnikiem opisującym wieź społeczną jest także jej jakość, która odnoszona jest do charakteru emocji wywoływanych kontaktem z daną osobą. Energia emocjonalna, która jest zarówno elementem składowym więzi, jak i przyczyną decydującą (lub nie) o budowaniu więzi, sytuuje się na kontinuum pomiędzy pozytywnymi uczuciami (szczęście, miłość) a uczuciami negatywnymi (Turner, Stets 2009: 25). Obok stanów pośrednich między szczęściem, przyjemnością, radością a wrogością, złością, antypatią sytuować należy uczucia pośrednie. Prawidłowością o ogólnym charakterze jest to, że emocje jednostki związane są z utrzymywanymi więziami, zależne są od statusu społecznego partnera oraz intensywności utrzymywanych relacji (Fingerman, Hay, Birditt 2004: 801). Pozytywne emocje łączące ludzi są więziotwórcze, natomiast negatywny ładunek emocji związany z więziami prowadzić może do pojawienia się poczucia samotności, a także izolacji społecznej. W kręgu kultury zachodniej te więzi, które mają dobrowolny charakter, np. przyjaźnie, koleżeństwo czy relacje sąsiedzkie, jeśli są stresogenne ze względu na negatywne emocje, które im towarzyszą, ulegają rozwiązaniu (Fingerman, Hay, Birditt 2004: 795). Specyfiką więzi jest także to, że obok więzi, które są jednoznaczne co do kierunku uczuć, mogą występować i takie, które jednocześnie zawierają w sobie sprzeczny co do kierunku ładunek emocji. Więzi ambiwalentne to takie, w których zniechęcenie i złość łączona jest z czułością i zaprzyjaźnieniem. Ten rodzaj więzi łączy ludzi, którzy często wchodzą ze sobą w interakcje i jednocześnie są społecznie zobowiązani do utrzymywania ze sobą bliskich relacji społecznych. Ambiwalentne więzi pojawiają się najczęściej w relacjach rodzinnych, w tym małżeńskich. Choć często prowadzą do poczucia dyskomfortu, to jednocześnie ich wieloaspektowy charakter (wynikający z treści więzi i siły norm społecznych scalających jednostki w diady i struktury) powoduje, że nie są odrzucane. Tego rodzaju więzi dotyczą, choć rzadziej, również relacji nierodzinnych, a mianowicie łączących przyjaciół, a także współpracowników. Ambiwalencja więzi powodować może poczucie samotności w chwilach, w których negatywny poziom emocji osiąga apogeum, nie wywołuje jednak w sposób bezpośredni zjawiska osamotnienia.

Ostatnim z czynników mogących służyć ocenie więzi bezpośrednich jest ich moc, która dotyczy siły wzajemnych zobowiązań wynikających z faktu istnienia więzi. To, jakie standardy obowiązują $\mathrm{w}$ relacjach między jednostkami, wynika bezpośrednio z obowiązujących w danym środowisku normatywnych i aksjologicznych reguł. Normy i wartości określają, jaka jest optymalna liczba więzi, tak aby nie prowadzić ani do zjawiska saturacji więzi ani do zjawiska izolacji społecznej. Wpływają one również na wzajemne zobowiązania ludzi (de Jong Gierveld, Van Tilburg, Dykstra 2006: 491). Więzi o silnej mocy oparte są na respektowaniu norm, które nie tylko nakazują utrzymywanie relacji, ale przede wszystkim udzielanie wsparcia i pomocy, także wtedy, gdy niemożliwa jest rekompensata za nią. Poczucie społecznego zakorzenienia oparte jest właśnie na więziach silnych, co w efekcie tworzy barierę przed poczuciem społecznego osamotnienia. Wię- 
zi silne, nawiązując do ustaleń Granovettera, opierają sie na częstych relacjach społecznych, w jakie wchodzi jednostka z bliskimi dla niej osobami. Powodując w ten sposób zagęszczenie relacji społecznych, które motywując jednostkę do działania, ograniczają ryzyko izolacji społecznej (Granovetter 1983: 209). Więzi słabe dostarczają zasobów, które nie występują w środowisku społecznym jednostki, a zatem wpływają na osłabienie tendencji wiodącej do pojawienia się poczucia samotności. Są jednak więziami kruchymi, w tym sensie, że trzeba pielęgnować i aktualizować w trakcie powtarzanych spotkań i kontaktów.

Jeśli odniesiemy ów czteroelementowy model więzi do zjawiska osamotnienia, możemy zauważyć, że decydujące jest kryterium ilościowe i odnoszące się do mocy więzi. Natomiast w przypadku samotności, na pojawienie się zjawiska zasadniczy wpływ ma treść więzi oraz ich jakość.

\section{BIBLIOGRAFIA}

Baltes M. M, Carstensen L. L. (1999), Social-psychological theories and their application to aging: from individual to collective, [w:] V.L. Bengtson, K.W. Schaie (eds.), Handbook of Theories of Aging, Springer, New York.

Beck U. (2002), Społeczeństwo ryzyka. W drodze do innej nowoczesności, Scholar, Warszawa.

Blieszner R., Adams R. (1992), Adult Friendship, Sage, Newbury Park.

Bok S. (1982), Secrets: On the Ethics of Concealment and Revelation. Pantheon Books, New York.

Bourdieu P. (1986) The forms of capital, [w:]. J. Richardson (ed.), Handbook of Theory and Research for the Sociology of Education, Greenwood, New York.

Bruhn J. (2011), Efekt grupy. Spójność społeczna i jej konsekwencje dla zdrowia, Szkoła Wyższa Psychologii Społecznej, Warszawa.

Castells M. (2007), Społeczeństwo sieci, Wydawnictwo Naukowe PWN, Warszawa.

de Jong Gierveld, J., Van Tilburg T., Dykstra P.A. (2006), Loneliness and Social Isolation, [w:] A. Vangelisti, D. Perlman (eds.), Cambridge Handbook of Personal Relationships, Cambridge University Press, Cambridge.

Fingerman K.L. Hay E.L., Birditt K.S., (2004), The Best of Ties, the Worst of Ties: Close, Problematic, and Ambivalent Social Relationships, ,Journal of Marriage and Family”, vol. 66.

Granovetter M., (1983), The strength of weak ties: A network theory revisited, „Sociological Theory", vol. 1.

Hortulanus R., Macheilseand A., Meeuwesen L. (2005), Social Isolation in Modern Society, Taylor \& Francis, London-New York.

Jacher W. (1987), Więź społeczna w teorii i praktyce, Wydawnictwo Uniwersytetu Śląskiego, Katowice.

Maffesoli M. (2008), Czas plemion. Schytek indywidualizmu w społeczeństwach ponowoczesnych, Wydawnictwo Naukowe PWN, Warszawa.

Ossowski S. (1983), O osobliwościach nauk społecznych, PWN, Warszawa.

Perlman D., Peplau L.A. (1981), Toward a social psychology of loneliness, [w:] S.W. Duck, R. Gilmour (eds.), Personal Relationships, vol. 3: Personal relationships in disorder, Academic Press, London.

Pinquart, M., Sórensen, S. (2001), Gender differences in self-concept and psychological wellbeing in old age: A meta-analysis, „Journal of Gerontology: Psychological Sciences”, vol. 56. 
Putnam R.D. (2008), Samotna gra w kręgle, Wydawnictwa Akademickie i Profesjonalne, Warszawa. Rybicki P. (1979), Struktura społecznego świata, PWN, Warszawa.

Schacht R. (1971), Alienation, Anchor Books, New York.

Seeman M. (1975), Alienation Studies, „Annual Review of Sociology”, vol. 1.

Small M. L. (2009), Unanticipated Gains: Origins of Network Inequality in Everyday Life, Oxford University Press, Oxford.

Stroebe W., Stroebe M., Abakoumkin G., Schut H. (1996). The role of loneliness and social support in adjustment to loss: A test of attachment versus stress theory, „Journal of' Personality and Social Psychology", vol. 70.

Szczepański J., (1965), Elementarne pojęcia socjologii, PWN, Warszawa.

Szukalski P. (2002), Przepływy międzypokoleniowe i ich kontekst demograficzny, Wydawnictwo Uniwersytetu Łódzkiego, Łódź.

Turner J.H., Stets J.E. (2009), Socjologia emocji, Wydawnictwo Naukowe PWN, Warszawa.

Turowski J. (1993), Socjologia. Małe struktury społeczne, TN KUL, Lublin.

Van Tilburg T. (1990), The size of the supportive network in association with the degree of loneliness, [w:] C.P.M. Knipscheer, T.C. Antonucci (eds.), Social Network, Research: Substantive Issues and Methodological Questions, Swets \& Zeitlinger, Lisse.

Waite L., Gallagher M. (2000), The Case for Marriage: Why Married People are Happier, Healthier and Better of Financially, Doubleday, New York.

Watters E. (2004), Urban Tribes: A Generation Redefines Friendship, Family and Commitment, Bloomsbury, New York.

Weiss R. S. (1973), Loneliness: The Experience of Emotional and Social Isolation, MIT Press Cambridge Mass.

Westin A. (1968), Privacy and Freedom, Ateneum, New York.

Dahlin E., Kelly E., Moen P. (2008), Is work the new neighborhood? Social Ties in the Workplace, Family, and Neighborhood, ,The Sociological Quarterly”, vol. 49.

\section{Social bonds and the phenomenon of loneliness and isolation}

\section{Summary}

In modern societies, the number of people who are socially isolated and experience constant feeling of loneliness is increasing. Main causes of this social isolation are associated with both inherent features of an individual and features of structures such as family and local community. An isolated person is a person who has limited number of significant others. Nevertheless, loneliness may also occur when a person is a part of a lot of social relations. The feeling of loneliness is therefore an individually experienced discomfort resulting from a subjective evaluation of the desired and the existing network of social relations. Both phenomena are threats to the welfare of individuals and at the same time are a challenge for organizations which are dealing with social policy. An analytical category which provides the diagnosis of loneliness and isolation is the social bond. The assessment of deficits associated with social bonds and can be performed measuring following criteria: quantity, quality and potency of the social bond.

Keywords: loneliness, social isolation, social bond, structure of bonds. 